\title{
Long-term plant community development as influenced by revegetation techniques
}

\author{
GREGORY J. NEWMAN AND EDWARD F. REDENTE
}

Authors are research associate, Natural Resource Ecology Laboratory, Colorado State University, Fort Collins, Colo. 80523 and professor, Rangeland Ecosystem Science Department, Colorado State University, Fort Collins, Colo. 80523.

Abstract

A revegetation techniques study was initiated during the fall of 1976 in northwestern Colorado in a disturbed sagebrush (Artemisia tridentata Nutt.) community. The study included 2 irrigation treatments, three seed mixtures, 2 seeding techniques, and 2 fertilization treatments. Short-term results were published and conclusions were made regarding the initial success of each treatment. The objective of the current study was to determine the effects of each treatment on plant community production, species composition, and species diversity after 20 years of plant community development.

Among irrigated plots, the native seed mixture produced greater aboveground biomass compared to an introduced mixture and a mixture of both native and introduced species (combination seed mixture). The native seed mixture also resulted in greater total species richness than the introduced mixture when averaging over all other treatments. Altered seeding rate ratios among life forms as well as altered seeding methods (drill versus broadcast seeding) did not significantly alter plant community development after 20 years. However, a single application of nitrogen and phosphorus significantly increased grass production on plots seeded to the combination seed mixture.

All revegetation plots have remained grass-dominated. However, shrub biomass was greater in the native and combination mixtures than in the introduced mixture under initial irrigated conditions in part due to successful establishment and growth of four-wing saltbush (Atriplex canescens Pursh Nutt.). Thus, the seed mixtures evaluated in this study have resulted in distinctly different plant communities and demonstrate that such initial treatments can influence long-term plant community development on severely disturbed rangelands. Broadcast seeding a native seed mixture that has been irrigated for 2 growing seasons without fertilization appears to be an effective long-term combination of cultural revegetation practices.

Key Words: seeding, seed mixtures, fertilization, irrigation, succession, reclamation, restoration

Self-sustaining rangeland ecosystems provide ecologically important functions such as the genesis, fertility, and stability of soils; cycling of nutrients; maintenance of genetic diversity; and

The Colorado State University Agricultural Experiment Station funded the research. The authors wish to thank Russell S. Sydnor for his assistance with field sample collection.

Manuscript accepted 28 Jan. 01
Resumen

En el otoño de 1976 se inició en el noroeste de Colorado un estudio de técnicas de revegetación en una comunidad disturbada de "Sagebrush" (Artemisia tridentata Nutt.). El estudio incluyo 2 tratamientos de irrigación, 3 mezclas de semilla, 4 técnicas de siembra y 2 tratamientos de fertilización. Los resultados a corto plazo se publicaron y se realizaron conclusiones respecto al éxito inicial de cada tratamiento. El objetivo del presente estudio fue determinar los efectos de cada tratamiento en la producción de la comunidad vegetal, la composición de especies y la diversidad de especies después de 20 años de desarrollo de la comunidad. Entre las parcelas irrigadas, la mezcla de especies nativas produjo una mayor cantidad de biomasa aérea en comparación con una mezcla de semillas de especies introducidas y una mezcla de ambas especies nativas e introducidas (combinación de mezclas de semillas). Cuando se promediaron todos los tratamientos la mezcla de semillas nativas también resulto en una mayor riqueza de especies que la mezcla de semillas introducidas. Relaciones alteradas de dosis de siembra entre formas de vida así como métodos de siembra alterados (hileras contra distribución de semilla al voleo) no alteraron significativamente el desarrollo de la comunidad vegetal después de 20 años. Sin embargo, una sola aplicación de nitrógeno y fósforo incrementaron significativamente la producción de zacate en las parcelas sembradas con la combinación de mezclas de semillas. Todas las parcelas de revegetación han permanecido dominadas por zacates. Sin embargo, bajo condiciones iniciales de irrigación, la biomasa de arbustos fue mayor en la mezcla de nativas y en al combinación de mezclas que en la mezcla de introducidas, en parte debido al éxito en el establecimiento y crecimiento del "Four-wing saltbush" (Atriplex canescens Pursh Nutt.). Así, las mezclas de semillas evaluadas en este estudio han resultado en distintas comunidades vegetales y han demostrado que los tratamientos iniciales pueden influenciar el desarrollo a largo plazo de la comunidad vegetal de pastizales severamente degradados. La siembra al voleo de una mezcla de semilla nativas que ha sido irrigadas durante 2 estaciones de crecimiento y sin fertilización parece ser una combinación de prácticas culturales de revegetación efectiva a largo plazo

the preservation of natural beauty inherent in open spaces (West 1993). These ecosystems also provide economically important commodities such as forage, water, minerals, energy, building materials, and numerous recreational opportunities (National Research Council 1994). Overuse of these commodities often results in intense soil disturbances. Drastic soil disturbances that degrade rangeland ecosystems impair inherent ecological func- 
tions because they remove excessive amounts of vegetation, destabilize ground surfaces, and alter ecosystem structure.

Successful reclamation of intensely disturbed soil is needed because: (1) it can help restore ecosystem structure and function by accelerating the establishment of diverse, self-sustaining plant communities, (2) without it, disturbed areas can remain depauperate of vegetation for many years (Knabe 1965), (3) it can help stabilize erosion-prone sites and reestablish lost commodities and services, and (4) certain federal and state reclamation laws require that plant diversity, canopy cover, and production on reclaimed sites be equal to or greater than the surrounding natural vegetation (Surface Mining Control and Reclamation Act 1977).

Restoration ecologists are typically concerned with meeting certain operationally defined reclamation "success criteria" within short time scales. Such short-term emphasis has arisen from (1) the time scale associated with bond release requirements in various state and federal laws and (2) the difficulties associated with initially establishing vegetation on severely disturbed sites. Consequently, restoration ecologists often utilize cultural practices to aid plant community establishment and development. However, funding is often limited for long-term monitoring, evoking the question: can initial short-term treatments have predictable long-term consequences? If initial revegetation techniques can, in a predictable fashion, direct the long-term outcome of plant community development on disturbed sites, restoration ecologists may be able to adopt a more long-term perspective aimed at achieving specific restoration goals.

The goals for successful rangeland reclamation, although widely debated because of different land use objectives, generally focus on short-term site stabilization and long-term ecosystem sustainability. DePuit (1988) stated that successful rangeland reclamation should provide adequate soil stabilization, support for desired land uses, ecological stability, and self-maintenance. For mining related disturbances, Redente and DePuit (1988) stated that reclamation should aim to: (1) provide immediate control of wind and water erosion by stabilizing the disturbed site with vegetation and (2) "...establish a diverse, effective, and self-sustaining plant community."

Reclamation is generally successful at meeting initial vegetation cover and production goals on various soil disturbances. However, the long-term efficacy of vari- ous revegetation practices has not been adequately documented. Additionally, although various revegetation practices have been shown to yield productive plant communities on some sites, species diversity (richness) goals have proven difficult to achieve (Chambers et al. 1994, DePuit 1984, Hatton and West 1987, Redente et al. 1984, Sindelar 1980, Stark and Redente 1985). Thus, documenting the long-term effects revegetation practices have on developing plant communities when used on drastically disturbed rangelands is essential to meet reclamation goals.

In this paper we evaluate the long-term effects of various revegetation techniques on a disturbed site in northwestern Colorado. The specific objective of this study was to determine the long-term effects of initial irrigation treatments, seed mixtures, seeding techniques, and fertilizer applications on net primary production, species composition, and species richness.

\section{Materials and Methods}

A detailed account of the study site location and original study methods can be found in Doerr et al. (1983). The study was initiated during the fall of 1976 in the Piceance Basin about $65 \mathrm{~km}$ northwest of Rifle, Colo. (39 $\left.54^{\prime} 14^{\prime \prime} \mathrm{N}, 108^{\circ} 24^{\prime} 03^{\prime \prime} \mathrm{W}\right)$ at an elevation of $2,200 \mathrm{~m}$. The study area was classified within the Mid-Elevation Big Sagebrush/Moderately Deep Loams Phyto-edaphic Unit as described by Teidman and Terwilliger (1978). Big sagebrush (Artemisia tridentata Nutt.) is the dominant species in undisturbed plant communities. Common under story species include: western wheatgrass (Agropyron smithii Rydb.), prairie junegrass (Koeleria macrantha (Ledeb.) J.A.), Indian ricegrass (Oryzopsis hymenoides (R. \& S.) Ricker), Needle-and-thread grass (Stipa comata Trin. \& Rupr.), carpet phlox (Phlox hoodii Richards), and scarlet globemallow (Sphaeralcea coccinea (Pursh.) Rydb.). Detailed soil characteristics prior to disturbance can be found in Doerr et al. (1983). Soils on the site were fine loamy, mixed, Borillic Camborthids. Mean annual precipitation (MAP) on the site is $282 \mathrm{~mm}$, with half of this precipitation received as snow.

\section{Experimental Design}

To create an intensive soil disturbance, six $(16 \times 92.5 \mathrm{~m})$ blocks of land were scraper excavated to a depth of $1 \mathrm{~m}$ in the fall of 1976. The excavated material (including both topsoil and rockier subsoil) was then mixed and returned to each site, creating a rocky growth medium with levels of nitrogen $(\mathrm{N})$ and phosphorus $(\mathrm{P})$ that were approximately half that of predisturbance levels (Doerr et al. 1983). The experimental design of the study consisted of a completely randomized, split-splitsplit plot, factorial experiment with 3 replications (Fig. 1). The treatments applied in 1976 included irrigation, seed mixtures, seeding techniques, and fertilization.

Irrigation treatments included either the addition of supplemental water on a weekly basis throughout the growing season (beginning in early June) for 2 years (1977 and 1978) or no irrigation. The amount of water added to irrigated plots brought the total water received (precipitation + irrigation) to $2.5 \mathrm{~cm}^{\text {week }}{ }^{-1}$. Supplemental water was applied with a sprinkler irriga-

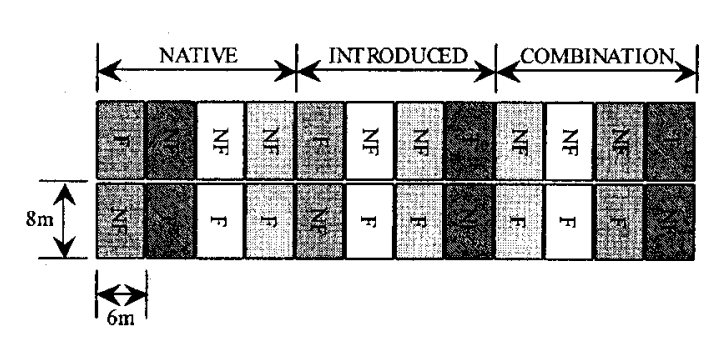

\section{LEGEND}

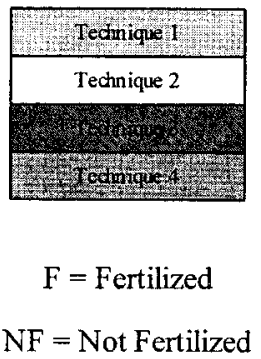

Fig. 1. One of 3 replicate blocks per each irrigation treatment illustrating the split-split-split randomized complete block experimental design used in the study. Three of these blocks were irrigated for the first 2 growing seasons of the study and 3 were not irrigated. The distribution of the seed mixtures (each mixture being applied to an area of 8 plots), the 4 seeding techniques (each technique being applied to east-west strips consisting of 2 plots), and the fertilization treatment (applied to individual plots) were completely randomized and differed for each irrigated or not irrigated replicate block. 
Table 1. The speciès seeded for each of the 3 seed mixtures used in the Revegetation Techniques Study. The seeding rate for each species as well as the total rate for each seeding technique are listed as pure live seed (PLS) in $\mathrm{kg} \mathrm{ha}^{-1}$.

\begin{tabular}{|c|c|c|c|c|c|}
\hline \multirow[b]{2}{*}{ Common Name } & \multirow[b]{2}{*}{ Scientific Name } & \multicolumn{4}{|c|}{ Seeding Rate PLS } \\
\hline & & Tech 1 & Tech 2 & Tech 3 & Tech 4 \\
\hline & & $\cdots$ & -2 & $\ldots \ldots$ & $\cdots \cdots$ \\
\hline \multicolumn{6}{|c|}{ Combination Seed Mixture } \\
\hline Nordan crested wheatgrass & Agropyron desertorum & 1.12 & 0.56 & 1.12 & 1.12 \\
\hline Siberian wheatgrass & Agropyron sibericum & 1.12 & 0.56 & 1.12 & 2.24 \\
\hline Critana thickspike wheatgrass & Agropyron dasystachyum & 1.12 & 0.56 & 2.24 & 3.36 \\
\hline Sodar streambank wheatgrass & Agropyron riparium & 1.12 & 0.56 & 2.24 & 3.36 \\
\hline Slender wheatgrass & Agropyron trachycaulum & 1.12 & 0.56 & 2.24 & 3.36 \\
\hline Regar meadow brome & Bromus biebersteinii & 1.12 & 0.56 & 1.12 & 2.24 \\
\hline Indian ricegrass & Oryzopsis hymenoides & 1.12 & 0.56 & 2.24 & 2.24 \\
\hline Green needlegrass & Stipa viridula & 1.12 & 0.56 & 2.24 & 3.36 \\
\hline Durar hard fescue & Festuca ovina duriscula & 0.56 & 0.28 & 0.56 & 1.12 \\
\hline Madrid yellow sweetclover & Melilotus officinalis & 0.56 & 0.28 & 0.56 & 0.56 \\
\hline Sweetvetch & Hedysarum boreale & 1.12 & 0.56 & 1.12 & 1.68 \\
\hline Globemallow & Sphaeralcea munroana & 0.56 & 0.56 & 0.56 & 1.12 \\
\hline Lewis flax & Linum lewisii & 0.56 & 0.56 & 0.56 & 1.12 \\
\hline Arrowleaf balsamroot & Balsamorhiza sagittata & 1.12 & 0.56 & 1.12 & 1.68 \\
\hline Fourwing saltbush & Atriplex canescens & 1.12 & 4.48 & 0.00 & 0.00 \\
\hline Stansbury cliffrose & Cowania mexicana stansburiana & 1.12 & 3.36 & 0.00 & 0.00 \\
\hline Winterfat & Ceratoides lanata & 1.12 & 2.24 & 0.00 & 0.00 \\
\hline \multirow[t]{2}{*}{ Green ephedra } & Ephedra viridis & 1.12 & 2.24 & 0.00 & 0.00 \\
\hline & Total & 17.92 & 19.60 & 19.04 & 28.56 \\
\hline \multicolumn{6}{|c|}{ Native Seed Mixture } \\
\hline Rosana western wheatgrass & Agropyron smithii & 1.12 & 0.56 & 3.36 & 4.48 \\
\hline Sodar streambank wheatgrass & Agropyron riparium & 1.12 & 0.56 & 1.12 & 2.24 \\
\hline Bearded bluebunch wheatgrass & Agropyron spicatum & 1.12 & 0.56 & 2.24 & 4.48 \\
\hline Indian ricegrass & Oryzopsis hymenoides & 1.12 & 0.56 & 2.24 & 4.48 \\
\hline Green needlegrass & Stipa viridula & 1.12 & 0.56 & 2.24 & 4.48 \\
\hline Shermans big bluegrass & Poa secunda & 1.12 & 0.56 & 1.12 & 1.12 \\
\hline Alkali sacaton & Sporobolus airoides & 0.56 & 0.28 & 0.56 & 1.12 \\
\hline Globemallow & Sphaeralcea munroana & 0.56 & 0.28 & 0.56 & 1.12 \\
\hline Sweetvetch & Hedysarum boreale & 1.12 & 0.56 & 1.12 & 1.12 \\
\hline Palmer penstemon & Penstemon palmeri & 0.56 & 0.28 & 0.56 & 1.12 \\
\hline Stansbury cliffrose & Cowania mexicana stansburiana & 2.24 & 4.48 & 0.00 & 0.00 \\
\hline Green ephedra & Ephedra viridis & 1.12 & 3.36 & 0.00 & 0.00 \\
\hline Fourwing saltbush & Atriplex canescens & 1.12 & 3.36 & 0.00 & 0.00 \\
\hline Winterfat & Ceratoides lanata & 1.12 & 2.24 & 0.00 & 0.00 \\
\hline \multirow[t]{2}{*}{ Antelope bitterbrush } & Purshia tridentata & 1.12 & 3.36 & 0.00 & 0.00 \\
\hline & Total & 16.80 & 21.84 & 15.68 & 26.88 \\
\hline \multicolumn{6}{|c|}{ Introduced Seed Mixture } \\
\hline Nordan crested wheatgrass & Agropyron desertorum & 1.12 & 0.56 & 2.24 & 3.36 \\
\hline Siberian wheatgrass & Agropyron sibericum & 1.12 & 0.56 & 1.12 & 2.24 \\
\hline Jose tall wheatgrass & Agropyron elongatum & 1.12 & 0.56 & 2.24 & 3.36 \\
\hline Luna pubescent wheatgrass & Agropyron trichophorum & 1.12 & 0.56 & 1.12 & 2.24 \\
\hline Oahe intermediate wheatgrass & Agropyron intermedium & 1.12 & 0.56 & 1.12 & 2.24 \\
\hline Manchar smooth brome & Bromus inermis & 1.12 & 0.56 & 1.12 & 2.24 \\
\hline Regar meadow brome & Bromus biebersteinii & 1.12 & 0.56 & 2.24 & 4.48 \\
\hline Vinal Russian wildrye & Elymus junceus & 1.12 & 0.56 & 1.12 & 2.24 \\
\hline Ladak alfalfa & Medicaga sativa & 0.56 & 0.28 & 0.56 & 1.12 \\
\hline Madrid yellow sweetelover & Melilotus officinalis & 0.56 & 0.28 & 0.56 & 1.12 \\
\hline Lutana cicer milkvetch & Astragalus cicer & 0.56 & 0.56 & 0.56 & 1.12 \\
\hline Sainfoin & Onobrychis viciaefolia & 0.56 & 0.56 & 0.56 & 1.12 \\
\hline Bouncing bet & Saponaria officinalis & 1.12 & 1.12 & 1.12 & 2.24 \\
\hline Small burnet & Sanguisorba minor & 1.12 & 1.12 & 1.12 & 2.24 \\
\hline Siberian peashrub & Caragana arborescens & 1.12 & 4.48 & 0.00 & 0.00 \\
\hline \multirow[t]{2}{*}{ Russian olive } & Elaeagnus angustifolia & 2.24 & 4.48 & 0.00 & 0.00 \\
\hline & Total & 16.80 & 17.36 & 16.80 & 31.36 \\
\hline
\end{tabular}

tion system using impact heads. Three seed mixtures used included: (1) a combination mixture of 13 native and 5 introduced species, (2) a native mixture of 15 native species, and (3) an introduced mixture of 16 introduced species (Table 1). The 4 seeding techniques evaluated (T1-
T4) consisted of seeding the specified life forms for each seed mixture with the following methods and rates: (T1) grass, forb, and shrub species drill seeded (power-till seeder with packer wheels) at a rate of $17 \mathrm{~kg} \mathrm{ha}^{-1}$; (T2) grass, forb, and shrub species drill seeded at a rate of 19 $\mathrm{kg} \mathrm{ha}^{-1}$ (with a shrub seeding rate approximately 2 times greater than in T1 and a grass and forb seeding rate approximately one-half that of $\mathrm{T} 1$ ); (T3) grass and forb species drill seeded at a rate of $17 \mathrm{~kg} \mathrm{ha}^{-1}$; and (T4) grass and forb species broadcast seeded at a rate of $29 \mathrm{~kg} \mathrm{ha}^{-1}$ and hand- 
Table 2. ANOVA table illustrating main effects and their interactions for the response varaiable of $\log ($ total biomass).

\begin{tabular}{llcc}
\hline \hline Treatment Interaction(s) & DF & F Statistic & p Value \\
\hline Trrigation & 4 & 0.57 & 0.4918 \\
Mixture & 92 & 11.17 & 0.0001 \\
Irrigation*Mixture & 92 & 10.11 & 0.0001 \\
Technique & 92 & 0.74 & 0.5331 \\
Irrigation*Technique & 92 & 1.70 & 0.1716 \\
Mixture*Technique & 92 & 1.12 & 0.3553 \\
Irrigation*Mixture*Technique & 92 & 1.29 & 0.2712 \\
Fertilization & 92 & 1.69 & 0.1969 \\
Irrigation*Fertilization & 92 & 0.02 & 0.8874 \\
Mixture*Fertilization & 92 & 2.43 & 0.0938 \\
Irrigation*Mixture*Fertilization & 92 & 0.49 & 0.6134 \\
Technique*fertilization & 92 & 0.38 & 0.7694 \\
Irrigation*Technique*Fertilization & 92 & 1.00 & 0.3963 \\
Mixture*Technique*Fertilization & 92 & 0.50 & 0.8061 \\
Irrigation*Mixture*Technique*Fertilization & 92 & 0.72 & 0.6376 \\
\hline
\end{tabular}

raked to cover with soil (Table 1 ). The 2 fertilization treatments included: (1) the application of $112 \mathrm{~kg} \mathrm{~N} \mathrm{ha}^{-1}$ and $90 \mathrm{~kg} \mathrm{P}$ $\mathrm{ha}^{-1}$ and (2) no fertilizer. All treatments were allocated among a total of $144(8 \times 6$ $\mathrm{m})$ experimental plots. After seeding, the entire study was hydro-mulched with wood fiber at a rate of $2.2 \mathrm{MT}^{-1} \mathrm{a}^{-1}$.

\section{Sampling Methodology}

We assessed plant community development in each plot by clipping current year aboveground biomass by species inside each of 5 randomly located $0.5 \times 1.0 \mathrm{~m}$ $\left(0.5 \mathrm{~m}^{2}\right)$ quadrats in June of 1997 . Individuals of each species in all five quadrats were harvested together, ovendried at $50^{\circ} \mathrm{C}$ for 48 hours, and weighed. We obtained plant species richness (i.e. the mean number of species encountered per plot) from the total number of species encountered in each of the 5 quadrats sampled per plot.

To compare the plant communities present on the experimental plots to a reference area that had not been severely modified by excavation but had been exposed to cattle and wildlife grazing for numerous years prior to our study, we used data sampled in an adjacent reference area during the years of 1987, 1989, 1991, and 1992. Four replicate reference plots, each $500 \mathrm{~m}^{2}$ in area, were sampled with 10 randomly placed $0.5 \mathrm{~m}^{2}$ quadrats.

\section{Data Analysis}

Differences between, and interactions among, treatments were analyzed using four-way analysis of variance (ANOVA) techniques for a split-split-split plot experimental design. The analyses were run by life form as well as total production for each treatment using the MIXED proce(loss of precision), while comparisons between seed mixtures (factor B) within a given level of irrigation (factor A) were more sensitive (Kuehl 1994). This tendency generally occurs because of pooled error variances and differing degrees of freedom in split-plot experimental designs (Steel and Torrie 1980).

\section{Results and Discussion}

\section{Irrigation and Seed Mixtures Biomass production}

Initially, in 1978, total biomass of both the combination and introduced seed mixtures was greater than the native mixture on irrigated plots (Doerr et al. 1983). Conversely, on non-irrigated plots, total biomass in the native seed mixture was greater than in both the combination and introduced mixtures. However, by 1979 , total biomass was roughly equal between all 3 seed mixtures on both irrigated and non-irrigated plots.

Irrigation also increased grass and forb biomass in 1978 and 1979 , especially in the introduced seed mixture. This increase corresponded with a decrease in shrub biomass (Doerr et al. 1983). These short-term results are consistent with those of May et al. (1971) and DePuit et al. (1982). Thus, irrigation for 2 growing seasons in a sagebrush steppe ecosystem may initially promote rapid grass production and aid in short-term erosion control. However, the long-term consequences of short-term irrigation appear to be different.

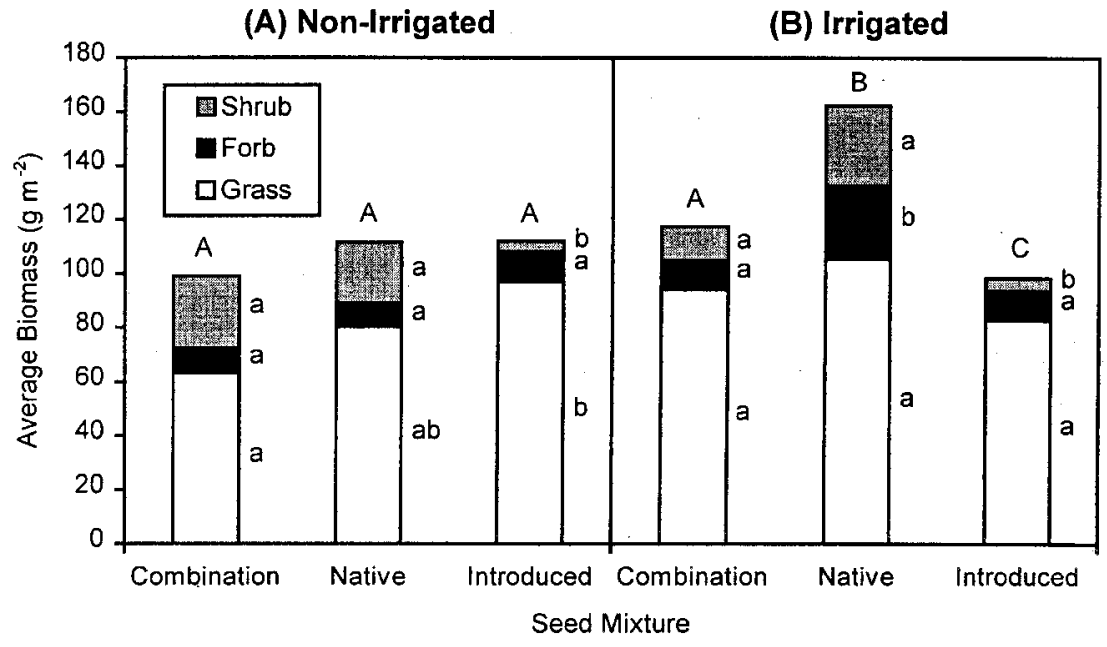

Fig. 2. (A) Mean total aboveground biomass of each seed mixture by life form among nonirrigated plots. (B) Mean total aboveground biomass of each seed mixture by life form among irrigated plots. Mean total biomass values with different upper-case letters within each irrigation treatment among seed mixtures are significantly different $(p<0.05)$. Mean grass, forb, and shrub biomass values within each irrigation treatment among seed mixtures with different lower-case letters are significantly different $(p<0.05)$. 
By 1997 , the native seed mixture produced greater total biomass than both the combination and introduced mixtures on irrigated plots (Fig. 2-B). Additionally, the combination seed mixture also produced greater total biomass than the introduced mixture when irrigated. However, on nonirrigated plots, there were no differences in total biomass among the 3 seed mixtures (Fig. 2-A). Thus, the 3 seed mixtures studied were found to be equally productive under non-irrigated conditions, but the native seed mixture out-produced both the combination and introduced seed mixture (after 20 years) when irrigated for 2 growing seasons. This interaction between irrigation and seed mixture was largely caused by increased native forb and shrub biomass under irrigated conditions.

Mean forb biomass was greater in the native seed mixture than the combination and introduced seed mixtures when irrigated (Fig. 2-B). Forb biomass in the native mixture was almost 3 times as great as that in either the combination or introduced mixture (Fig. 2-B). However, no differences in forb biomass were observed among the 3 seed mixtures when irrigation was not applied (Fig. 2-A). Mean shrub biomass in both the combination and native seed mixtures was significantly greater than in the introduced seed mixture under irrigated conditions (Fig. 2-B). Similarly, shrub biomass in both the combination and native seed mixture was also greater than in the introduced mixture when not irrigated (Fig. 2-A).

\section{Species composition}

The influence of irrigation on species composition was still evident after 20 years. The dominant species on all irrigated plots was hard fescue (Festuca ovina var. duriscula A. Gray ex. Port. and Coult.). Fescue biomass averaged $24 \mathrm{~g}$ $\mathrm{m}^{-2}$, which represented $19 \%$ of the total biomass produced on irrigated plots. However, on all non-irrigated plots, hard fescue was a minor species, producing only $3 \mathrm{~g} \mathrm{~m}^{-2}$ and representing only $3 \%$ of the total biomass. The dominant species on non-irrigated plots was crested wheatgrass (Agropyron desertorum (Fisch.) Schult.), which contributed $17 \%$ of the total biomass compared to $14 \%$ of the total biomass on irrigated plots (where it was the second most dominant species).

The lack of long-term studies evaluating species composition after irrigation makes it difficult to address the hypothesis that irrigation favors the establishment and subsequent persistence of certain species. There are many studies that report on the short-term effects of irrigation during reclamation, but these studies provide little insight into long-term consequences of irrigation. For example, DePuit et al. (1982) evaluated individual species response to irrigation in southeastern Montana and concluded that western wheatgrass, slender wheatgrass (Agropyron trachycaulum (Link) Malte ex H.F. Lewis), smooth bromegrass (Bromus inermis Leyss.), and yellow sweetclover (Melilotus officinale) were species that showed a positive response to irrigation after 2 growing seasons. Results of our study are contrary to those of DePuit et al. (1982) for all species except smooth bromegrass. Smooth bromegrass showed an increase in production with irrigation, but the remaining species showed either a decline in production (western wheatgrass) or no effect after 20 years. Further research is needed to address the hypothesis that irrigation favors the establishment and long-term persistence of certain species because of differences in environmental conditions and competitive interactions among species.

Regardless of the mechanisms underlying potential long-term community level and species specific irrigation effects, restoration ecologists need to weigh: (1) the costs of initial irrigation, (2) the practical importance of possible long-term irri- gation effects, and (3) the necessity for rapid site stabilization that may be achieved with irrigation (Doerr et al. 1983, Farmer et al. 1974, Ries and Day 1978) before a final decision is made.

The seed mixtures used in this study also influenced species composition of the established communities after 20 years (Table 3). The plant communities present on plots seeded to each of the 3 seed mixtures have remained dominated by species that were originally seeded in 1976, indicating that the species originally seeded have inhibited colonization by neighboring species. For example, of the 18 species initially seeded in the combination seed mixture, 13 species $(72 \%)$ were still present after 20 years. These 13 species represented $67 \%$ of the total biomass reported for the combination mixture. Similarly, 11 species of the 15 originally seeded ( $73 \%$ ) were still present in the native seed mixture; representing $76 \%$ of the total biomass of the native mixture. Conversely, only 7 species of the 16 seeded $(44 \%)$ in the introduced mixture were still present after 20 years. However, these 7 species represented $94 \%$ of the total biomass of the introduced mixture.

These results are consistent with those of Redente et al. (1997) on a top soiled coal mine in northwestern Colorado. In this study, the 6 most productive species

Table 3. Mean percent species composition of each seed mixture compared to the mean percent species composition of the native reference area. Major species shown comprise $\geq 5 \%$ of the mean total biomass on any of the 3 seed mixtures and/or the undisturbed reference area plant community. All other species (not shown) comprise $<5 \%$ of the mean total biomass on each of the 3 seed mixtures and $<5 \%$ on the undisturbed plant community. These minor species (not shown) are labeled as 'Other'. Standard error's (s.e.) are also given for each percentage value.

\begin{tabular}{|c|c|c|c|c|c|c|c|c|}
\hline \multirow{2}{*}{$\begin{array}{l}\text { Species } \\
\text { Code }^{1}\end{array}$} & \multicolumn{2}{|c|}{ Combination } & \multicolumn{2}{|c|}{ Native } & \multicolumn{2}{|c|}{ Introduced } & \multicolumn{2}{|c|}{ Undisturbed } \\
\hline & $(\%)$ & (s.e.) & $(\%)$ & (s.e.) & $(\%)$ & (s.e.) & $(\%)$ & (s.e.) \\
\hline Agrdes & 30 & 3.07 & 2 & 0.88 & 18 & 2.12 & $\mathrm{~T}^{2}$ & $\mathrm{~T}$ \\
\hline Agrint & $\mathrm{T}$ & $\mathrm{T}$ & 1 & 0.37 & 40 & 4.45 & $\mathrm{~T}$ & $\mathrm{~T}$ \\
\hline Agrsmi & 9 & 1.29 & 7 & 1.04 & $\mathrm{~T}$ & $\mathrm{~T}$ & 2 & 0.02 \\
\hline Agrspi & $\mathrm{T}$ & $\mathrm{T}$ & 32 & 4.31 & $\mathrm{NP}^{3}$ & NP & $\mathrm{T}$ & $\mathrm{T}$ \\
\hline Broine & 8 & 1.32 & 1 & 0.49 & 6 & 1.15 & NP & NP \\
\hline Elyjun & $\mathrm{T}$ & $\mathrm{T}$ & $\mathrm{T}$ & $\mathrm{T}$ & 21 & 2.53 & NP & NP \\
\hline Fesovi & 20 & 4.54 & 13 & 3.70 & $\mathrm{~T}$ & $\mathbf{T}$ & NP & NP \\
\hline Koemac & NP & NP & $\mathrm{T}$ & $\mathrm{T}$ & $\mathrm{T}$ & $\mathbf{T}$ & 6 & 0.06 \\
\hline Poasec & $\mathrm{T}$ & $\mathrm{T}$ & 6 & 2.53 & $\mathrm{~T}$ & $\mathrm{~T}$ & 2 & 0.02 \\
\hline Hedbor & 6 & 1.20 & 10 & 2.99 & $\mathrm{~T}$ & $\mathrm{~T}$ & $\mathrm{~T}$ & $\mathrm{~T}$ \\
\hline Medsat & $\mathrm{T}$ & $\mathrm{T}$ & 1 & 0.95 & 7 & 1.42 & NP & NP \\
\hline Arttri & 3 & 1.49 & 2 & 1.36 & 3 & 1.59 & 63 & 0.63 \\
\hline Atrcan & 7 & 1.93 & 7 & 2.29 & $\mathrm{~T}$ & $\mathrm{~T}$ & NP & NP \\
\hline Ephvir & 2 & 0.68 & 6 & 3.47 & NP & NP & NP & NP \\
\hline Other & 15 & & 12 & & 5 & & 27 & \\
\hline Total & 100 & & 100 & & 100 & & 100 & \\
\hline
\end{tabular}

'Species codes are as follows: 'Agrdes' $=$ Agropyron deserortum, 'Agrint' $=A$. intermedium. 'Agrsmi' $=A$. smithii, 'Agrspi' = A. Spicatum, 'Broine' = Bromus inermis, 'Elyjun' = Elymus junceus, 'Fesovi' = Festuca ovina var. duriscula, 'Koemac' = Koeleria macrantha, 'Poasec' = Poa secunda, 'Hedbor' = Hedysarum boreale, 'Medsat' = Medicago sativa, 'Arttri' = Artemisia tridentata, 'Atrcan' = Atriplex canescens, and 'Ephvir' = Ephedra viridis.

${ }^{2} \mathrm{~T}=$ Trace amount present.

${ }^{3} \mathrm{NP}=$ Not present. 
(smooth bromegrass; basin wildrye (Elymus cinereus); cicer milkvetch (Astragalus cicer L.); western wheatgrass; intermediate wheatgrass (Agropyron intermedium (Host) Beauv.); and crested wheatgrass) together accounted for $90 \%$ of the total biomass of all top soiled treatments after 10 years.

Distinctly different plant communities resulted from the use of seed mixtures with all native or all introduced species. A more shrub-based plant community, as well as a diverse mixture of other species, developed on plots seeded with the native seed mixture. Conversely, because of poor establishment of seeded introduced shrub species (Doerr et al. 1983), a predominately grass community dominated by crested wheatgrass, intermediate wheatgrass, Russian wildrye (Elymus junceus (Fisch.) Nevski.), and smooth bromegrass developed on plots seeded to the introduced seed mixture. The biomass of these 4 grass species represented $85 \%$ of the total biomass reported for plots seeded to the introduced seed mixture.

These results are similar to those of Walker et al. (1995) on chained pinyonjuniper sites in Utah. In their study, crested wheatgrass was seeded on chained sites and was found to be increasing in terms of density and productivity after 20 years. Similar long-term species composition differences were reported by Sydnor (1999) on revegetation plots in Colorado that used seed mixtures similar to those used in this study. Perhaps seeded sites in sagebrush ecosystems reach a state that, analogous to recent state-transition (ST) models (Allen-Diaz and Bartolome 1998), requires substantial energy input to move the established community to a new community type.

\section{Species richness}

Finally, irrigation had no long-term effect on species richness after 20 years of plant community development. Species richness was not different between irrigated plots and non-irrigated plots when averaging over all treatments. There were no significant interactions for species richness between any other treatments.

The seed mixtures used in this study produced differences in species richness after 20 years. This main effect was not dependent upon any other treatment. Plots seeded to the introduced seed mixture had the lowest species richness after 20 years. The mean total number of species present on plots seeded to the combination mixture (10 species per plot) and native mixture (12 species per plot) was greater than on plots seeded to the introduced mixture (7 species per plot). Consequently, bond release requirements or long-term land use objectives may not be met (or maintained over longer time scales) when using solely introduced species. These results may be related to the different competitive abilities of the grasses seeded in both these seed mixtures. A study by Eissenstat and Caldwell (1988) showed that the competitive abilities of crested wheatgrass and bluebunch wheatgrass are markedly different due to differences in the ability of each species' root system to extract soil water.

\section{Seeding Techniques and Fertilization}

Short-term studies have shown that broadcast seeding is as effective as drill seeding when broadcast seeding rates are twice that of drill seeding (Doerr and Redente 1983, DePuit and Coenenberg 1979). This is contrary to the conventional short-term wisdom that drill seeding should perform better than broadcast seeding because drilling places seed at an optimum depth and in good contact with the soil environment. However, our 1997 results support the hypothesis that broadcast seeding can be equally effective as drill seeding in the long-term.
Of the 4 seeding techniques included, only comparisons among (a) the effects of the 2 seeding rate ratios ( $\mathrm{T} 1$ and $\mathrm{T} 2$ ) and (b) the effects of the 2 seeding methods (T3 and T4; drill and broadcast seeding of grass and forb species, respectively) were of specific a priori ecological interest. No differences existed between $\mathrm{T} 1$ and $\mathrm{T} 2$ for total biomass or biomass of individual life forms after 20 years. Similarly, no differences existed for total and life form biomass between T3 and T4. Species composition differed only slightly between $\mathrm{T} 1$ and $\mathrm{T} 2$ and $\mathrm{T} 3$ and $\mathrm{T} 4$ (Table 4). Species richness did not differ between $\mathrm{T} 1$ plots and $\mathrm{T} 2$ plots, nor did it differ between drill-seeded plots (T3) and broadcast seeded plots (T4). Thus, no differences were found between drill seeding (T3) and broadcast seeding (T4) for production among life forms, total production, and species richness.

However, some differences existed between fertilized and non-fertilized plots. Grass biomass was greater on plots seeded to the combination seed mixture on fertilized plots than on non-fertilized plots. Certain species appeared to have been influenced by the initial fertilization application. Hard fescue represented $16 \%$ of

Table 4. Percent species composition on seeding techniques $1,2,3$, and 4 . Seeding technique 1 consisted of drill seeding grass, forb, and shrub species in each seed mixture at a rate of $17 \mathrm{~kg} \mathrm{ha}^{-1}$. Conversely, seeding technique 2 consisted of drill seeding grass, forb, and shrub species at $17 \mathrm{~kg}$ $\mathrm{ha}^{-1}$, but with an increased shrub seeding rate and a decreased grass and forb seeding rate relative to technique 1 . Seeding technique 3 involved drill seeding grass and forb species in each seed mixture at a rate of $17 \mathrm{~kg} \mathrm{ha}^{-1}$. Seeding technique 4 involved broadcast seeding grass and forb species in each seed mixture at a rate of $29 \mathrm{~kg} \mathrm{ha}^{-1}$ and lightly covering the seed with soil. Species shown produced $\geq 5 \%$ of the total biomass on either seeding techniques 1 or 2 or on techniques 3 or 4. Species that comprise $<5 \%$ of the total biomass on seeding techniques 1 and 2 or 3 and 4 are labeled as 'Other species'. Standard error's (s.e.) are also shown.

\begin{tabular}{|c|c|c|c|c|}
\hline \multirow[b]{2}{*}{ Species } & \multicolumn{2}{|c|}{ Tech. 1 (>grass/forb) } & \multicolumn{2}{|c|}{ Tech. 2 (>shrub) } \\
\hline & $(\%)$ & (s.e.) & $(\%)$ & (s.e.) \\
\hline Agropyron desertorum & 18 & 3.1 & 17 & 2.4 \\
\hline Agropyron intermedium & 11 & 2.9 & 15 & 3.9 \\
\hline Agropyron smithii & 6 & 1.2 & 8 & 1.8 \\
\hline Agropyron spicatum & 10 & 3.1 & 6 & 2.8 \\
\hline Atriplex canescens & 6 & 1.5 & 10 & 1.9 \\
\hline Elymus junceus & 9 & 2.6 & 6 & 1.8 \\
\hline Ephedra viridis & 2 & 0.9 & 6 & 2.1 \\
\hline Festuca ovina var. duriscula & 11 & 3.1 & 6 & 2.2 \\
\hline Poa secunda & 5 & 2.0 & 3 & 1.1 \\
\hline Other species & 22 & & 23 & \\
\hline \multirow[t]{2}{*}{ Total composition } & 100 & & 100 & \\
\hline & \multicolumn{2}{|c|}{ Tech. 3 (drill) } & \multicolumn{2}{|c|}{ Tech. 4 (broadcast) } \\
\hline Species & $(\%)$ & (s.e.) & $(\%)$ & (s.e.) \\
\hline Agropyron desertorum & 15 & 2.9 & 18 & 3.2 \\
\hline Agropyron intermedium & 17 & 4.0 & 12 & 3.5 \\
\hline Agropyron smithii & 7 & 2.2 & 7 & 2.2 \\
\hline Agropyron spicatum & 16 & 4.1 & 14 & 3.7 \\
\hline Elymus junceus & 7 & 2.3 & 8 & 2.8 \\
\hline Festuca ovina var. duriscula & 11 & 3.1 & 13 & 3.5 \\
\hline Hedysarum boreale & 6 & 1.5 & 8 & 2.0 \\
\hline Other species & 21 & & 20 & \\
\hline Total composition & 100 & & 100 & \\
\hline
\end{tabular}


the total biomass produced on fertilized plots. On non-fertilized plots, fescue biomass represented only $7 \%$ of the total biomass. Otherwise, species composition on fertilized plots closely approximated species composition on non-fertilized plots.

Fertilization can lead to a more productive growth medium. Under non-equilibrium conditions (typical of disturbed sites), Huston (1979) hypothesized that conditions that increase the production potential of competitive species theoretically result in lower species richness because of increased competitive exclusion. Studies by Biondini and Redente (1986), Stark and Redente (1985), and Redente et al. (1997) in northwestern Colorado supported this hypothesis. However, results from this study (evaluating effects of a one-time application of $\mathrm{N}$ and $\mathrm{P}$ ) showed no significant decline in species richness on fertilized plots compared to non-fertilized plots.

This discrepancy may be related to differences in the length of time that these higher productivity conditions persist. For example, the stimuli evaluated by Stark and Redente (1985) were associated with soil characteristics (i.e. percent coarse fragments, depth to bedrock, topography, salt content, and soil fertility) that should have long-term influences on site productivity. Conversely, the initial one-time fertilization application evaluated in the current study may not have increased site productivity long enough to substantially increase the growth rates of highly competitive species and subsequently decrease species richness.

\section{Comparisons with an Adjacent \\ Reference Plant Community}

Native reference areas have been used as a standard to evaluate reclamation success for many reclamation projects (Chambers et al. 1994). Additionally, reference areas represent an objective standard against which the relative success of initial revegetation techniques can be evaluated.

Comparisons between mean total aboveground biomass on plots seeded to the 3 seed mixtures after 20 years differed from that of the reference plant community (Table 5). Mean total biomass (averaged over the years $1987,1989,1991$, and 1992) on the undisturbed area was $149 \mathrm{~g}$ $\mathrm{m}-2$. Total biomass in plots seeded to the combination and introduced seed mixtures were both less than the reference plant community (Table 5 ). However, total biomass in the native mixture was similar to the reference area.

Table 5. Mean and \% production for each seed mixture by life form versus the undisturbed reference area. Means are presented in $\mathrm{g} \mathrm{m}^{-2}$. Standard error's (s.e.) are also given for each percentage value.

\begin{tabular}{lcccccccc}
\hline \hline \multirow{2}{*}{$\begin{array}{l}\text { Cife } \\
\text { Form }\end{array}$} & \multicolumn{2}{c}{ Combination } & \multicolumn{2}{c}{ Native } & \multicolumn{2}{c}{ Introduced } & \multicolumn{2}{c}{ Undisturbed } \\
\cline { 2 - 8 } & Mean & $\%($ s.e. $)$ & Mean & $\%($ s.e. $)$ & Mean & $\%($ s.e.) & Mean & $\%($ s.e. $)$ \\
\hline & $\left(\mathrm{g} \mathrm{m}^{-2}\right)$ & & $\left(\mathrm{g} \mathrm{m}^{-2}\right)$ & & $\left(\mathrm{g} \mathrm{m}^{-2}\right)$ & & $\left(\mathrm{g} \mathrm{m}^{-2}\right)$ & \\
Grass & $79^{*}$ & $74(3)$ & $93^{*}$ & $71(3)$ & $90^{*}$ & $86(2)$ & 32 & $21(4)$ \\
Forb & 10 & $9(1)$ & 18 & $12(2)$ & 11 & $10(1)$ & 13 & $11(3)$ \\
Shrub & $19^{*}$ & $17(3)$ & $26^{*}$ & $17(3)$ & $4^{*}$ & $4(1)$ & 104 & $68(5)$ \\
Total & $108^{*}$ & 100 & 137 & 100 & $105^{*}$ & 100 & 149 & 100 \\
\hline
\end{tabular}

*Significantly different than the corresponding (same row) undisturbed reference area means at the 0.05 level.

The combination seed mixture produced similar total biomass as the reference plant community when irrigated, but less biomass when non-irrigated. Conversely, the introduced mixture produced less biomass than the reference area when irrigated, but similar biomass when non-irrigated. The native mixture, however, produced similar total biomass as the reference plant community on both irrigated and non-irrigated plots.

A relative comparison of life forms between the 1997 results of the experimental plots and the reference area may provide greater insight into plant community development. In terms of relative composition by life form, grass biomass represented $21 \%$ of the total production in the reference area, whereas forb and shrub biomass represented $11 \%$ and $68 \%$, respectively (Table 5 ). In contrast, plots seeded with the combination seed mixture had $74 \%$ grass biomass, $9 \%$ forb biomass, and $17 \%$ shrub biomass (Table 5 ). Similarly, the native seed mixture supported $71 \%$ grass biomass, $12 \%$ forb biomass, and $17 \%$ shrub biomass. Plots seeded with the introduced seed mixture had $86 \%$ grass biomass, $10 \%$ forb biomass, and only $4 \%$ shrub biomass (Table 5 ). Thus, on a relative biomass by life form basis, all 3 seed mixtures evaluated were dissimilar to the reference plant community after 20 years of plant community development.

The native and combination seed mixtures (regardless of irrigation treatment, seeding technique, and fertilization) closely resembled the reference area in terms of species richness. The mean number of species per plot (4 replicate plots sampled, each $500 \mathrm{~m}^{2}$ in area and sampled with ten, $0.5 \mathrm{~m}^{2}$ quadrats for a total area sampled of $5 \mathrm{~m}^{2}$ ) in the reference area was 5.6 species $\mathrm{m}^{-2}$. The maximum species richness obtained in any given seed mixture (averaging over all other treatments) in the experimental plots (48 plots; each $48 \mathrm{~m}^{2}$ in area and sampled with five, $0.5 \mathrm{~m}^{2}$ quadrats for a total area sampled of 2.5 $\mathrm{m}^{2}$ ) was 4.8 species $\mathrm{m}^{-2}$ in the native seed mixture. Similarly, the combination seed mixture yielded 4.2 species $\mathrm{m}^{-2}$. However, the introduced seed mixture yielded only 2.8 species $\mathrm{m}^{-2}$. Thus, species richness for both the native and combination seed mixtures was found to be qualitatively similar to the reference area after 20 years of plant community development, but lower for the introduced seed mixture.

\section{Conclusion}

Our results demonstrate that initial cultural practices can influence long-term plant community development over time. The original species seeded in each seed mixture evaluated have remained persistent over 20 years, especially on plots seeded with the combination and native seed mixtures. Therefore, we conclude that (1) initial seeding (within the limits of the species seeded in this study) of a disturbed semi-arid sagebrush site inhibited colonization of neighboring species, (2) initial irrigation increases the long-term productivity of the native seed mixture used in this study (especially forb and shrub species), (3) the 3 seed mixtures, despite inhibiting further colonization, have resulted in distinctly different plant communities after 20 years, and (4) broadcast seeding a native seed mixture that has been irrigated for 2 growing seasons without fertilization appears to be an effective long-term combination of cultural revegetation practices. These results lead us to hypothesize that (1) succession on re-seeded, severely disturbed sites in the semiarid intermountain west may closely resemble the "inhibition" model of plant succession originally described by Connell and Slatyer (1977), (2) barring any further disturbance, re-seeded sites may remain in a steady-state as defined by the ST model developed by Allen-Diaz and Bartolome (1998), and (3) secondary succession may differ between disturbed-non seeded sites and disturbed-re-seeded sites in the intermountain west. 


\section{Literature Cited}

Allen-Diaz, B. and J.W. Bartolome. 1998. Sagebrush-grass vegetation dynamics: Comparing classical and state-transition models. Ecol. Applic. 8:795-804.

Biondini, M. and E. F. Redente. 1986. Interactive effect of stimulus and stress on plant community diversity in reclaimed lands. Reclam. Reveg. Res. 4: 211-222.

Chambers, J., R. Brown and B. Williams. 1994. An evaluation of reclamation success on Idaho's phosphate mines. Rest. Ecol. 2: 4-16.

Connell, J.H. and R.O. Slatyer. 1977. Mechanisms of succession in natural communities and their role in community stability and organization. Amer. Natur. 111:1119-1143.

DePuit, E. J. 1984. Potential topsoiling strategies for enhancement of vegetation diversity on mined lands. p. 258-272 In: Third biennial symposium on surface coal mine reclamation on the Great Plains, Billings, Mont.

DePuit, E. J. 1988. Productivity of Reclaimed Lands - Rangelands. p. 93-129 In: L. R. Hossner, ed. Reclamation of Surface-Mined Lands. CRC Press, Inc., Boca Raton, Fla.

DePuit, E. J. and J. G. Coenenberg. 1979. Methods for establishment of native plant communities on topsoiled coal stripmine spoils in the Northern Great Plains. Reclam. Rev. 2: 75-83.

DePuit, E. J., C. L. Skilbred, and J. G. Coenenberg. 1982. Effects of two years of irrigation on revegetation of coal surfacemined land in South-Eastern Montana. J. Range Manage. 35: 67-74.

Doerr, T. B. and E. F. Redente. 1983. Seeded plant community changes on intensively disturbed soils as affected by cultural practices. Reclam. and Reveg. Res. 2: 13-24.

Doerr, T. B., E. F. Redente, and T. E. Sievers. 1983. Effect of cultural practices on seeded plant communities on intensively disturbed soils. J. Range Manage. 36: 423-428.
Eissenstat, D. M. and M. M. Caldwell. 1988. Competitive ability is linked to rates of water extraction: A field study of two aridland tussock grasses. Oecologia 63:153-158.

Farmer, E. E., R. W. Brown, B. Z. Richardson, and P. E. Packer. 1974. Revegetation research on the Decker Coal Mine in southeastern Montana. USDA Forest Service. Rep. INT-162. Ogden, Ut.

Hatton, T. J. and N. E. West. 1987. Early seral trends in plant community diversity on a recontoured surface mine. Vegetatio 73 : 21-29.

Huston, M. 1979. A general hypothesis of species diversity. The Amer. Natur. 113: 81-101.

Knabe, W. 1965. Observations on world-wide efforts to reclaim industrial waste land. Symposium of the Brit. Ecol. Soc. 5: 263-296.

Kuehl, R.O. 1994. Statistical principles of research design and aalysis. 2nd ed. Duxburg/Thompson Learning, Pacific Grove, Calif.

May, M., R. Lang, L. Lujan, P. Jacoby, and W. Thompson. 1971. Reclamation of strip mine spoil banks in Wyoming. Univ. of Wyo., Laramie, Wyo.

National Research Council. 1994. Rangeland Health: New methods to classify, inventory, and monitor rangelands. Nat. Acad. Press, Wash., D.C.

Redente, E., and E. DePuit. 1988. Reclamation of drastically disturbed rangelands. $p$. 559-584 In: P. Tueller, ed. Vegetation science applications for rangeland analysis and management. Klewer Acad. Publ., Boston, Mass.

Redente, E. F., T. McLendon, and W. Agnew. 1997. Influence of topsoil depth on plant community dynamics of a seeded site in northwestern Colorado. Arid Soil Res. and Rehab. 11:139-149.

Redente, E. F., T. B. Doerr, C. E. Grygiel, and M. E. Biondini. 1984. Vegetation establishment and succession on disturbed soils in northwest Colorado. Reclam. and Reveg. Res. 3:153-165.
Ries, R. E. and A. D. Day. 1978. Use of irrigation in reclamation in dry regions. $p$. 505-520 In: F. W. Schaller and P. Sutton eds. Reclamation of drastically disturbed lands. Amer. Soc. of Agron., Crop Science Soc. of Amer., and Soil Sci. Soc. of Amer., Madison, Wis.

SAS Institute. 1989-1996. SAS Institute, Cary, N. C.

Sindelar, B. W. 1980. Achicving revegetation standards on surface mined lands. Adequate reclamation of mined lands? - A symposium. Soil Conserv. Soc. of Amer., Western Agr. Exp. Sta., Billings, Mont.

Surface Mining Control and Reclamation Act, 1977. Surface mining control and reclamation act. P. L. 95-83.

Stark, J. M., and E. F. Redente. 1985. Soilplant diversity relationships on a disturbed site in northwestern Colorado. Soil Sci. Soc. of Amer. J. 49:1028-1034.

Steele, R. G. D. and J. H. Torrie. 1980. Principles and procedures of statistics: A biometrical approach. Second Ed. McGraw-Hill, Inc. New York, N. Y.

Sydnor, R. 1999. An evaluation of long-term plant community development on topsoil treatments overlying retorted oil shale. M.S. Thesis. Rangeland Ecosystem Sci. Dept., Colo. State Univ., Fort Collins, Colo.

Tiedeman, J.A. and C. Terwilliger. 1978. Phyto-edaphic classification of the Piceance Basin. Range Sci. Dept., Colo. State Univ., Fort Collins, Colo. $265 \mathrm{p}$.

Walker, S. C., R. Stevens, S. B. Monsen, and K. R. Jorgensen. 1995. Interaction between native and seeded introduced grasses for 23 years following chaining of Juniper-Pinyon woodlands. p. $372-380$. In: Proceedings: Wildland shrub and arid land restoration symposium. Intermountain Res. Sta., U.S. Forest Service, USDA, Las Vegas, Nev.

West, N. 1993. Biodiversity of rangelands. J. Range Manage. 46: 2-13. 